Intecoms: Journal of Information Technology and Computer Science

Volume 1 Nomor 2, Desember 2018

e-ISSN : 2614-1574

p-ISSN : 2621-3249

DOI : https://doi.org/10.31539/intecoms.v1i2.296

\title{
ANALISA DAN PERANCANGAN SISTEM PELAPORAN KINERJA PEGAWAI MENGGUNAKAN WORK SYSTEM FRAMEWORK DENGAN PEMODELAN UML
}

\section{ANALYSIS AND DESIGN OF EMPLOYEE PERFORMANCE ASSESSMENT SYSTEM USING WORK SYSTEM FRAMEWORK WITH UML MODELING}

\author{
Erid Ade Putra \\ Universitas Putra Indonesia YPTK Padang \\ eridadeputra@gmail.com
}

\begin{abstract}
Employee performance report is an important element in an organization. This report relates to activities undertaken by employees in accordance with their respective duties and the amount of allowances earned employees within one month of work. General Bureau is one of the agencies that require employee performance report where at this moment this report is still done manually. For that, needed a system in managing employee performance report. The system built is analyzed using work system framework method, to model the system to be built then used unified modeling language.
\end{abstract}

Keywords: Analysis and design, work system framework, unified modeling language, employee performance reporting application

\begin{abstract}
ABSTRAK
Laporan kinerja pegawai merupakan elemen yang penting dalam suatu organisasi. Laporan ini berkaitan dengan kegiatan-kegiatan yang dilakukan pegawai sesuai dengan tugasnya masing-masing serta besarnya tunjangan yang didapat pegawai dalam satu bulan kerja. Biro Umum merupakan salah satu instansi yang membutuhkan laporan kinerja pegawainya dimana pada saaat ini laporan ini masih dilakukan secara manual. Untuk itu, dibutuhkan suatu sistem dalam mengelola laporan kinerja pegawai. Sistem yang dibangun dianalisis menggunakan metode Work System Framework, untuk memodelkan sistem yang akan dibangun maka digunakan unified modelling language.
\end{abstract}

Kata Kunci : Analisa dan Perancangan, Work System Framework, Unified Modeling Language, Aplikasi Pelaporan Kinerja Pegawai

\section{PENDAHULUAN}

Laporan kinerja pegawai merupakan hal yang sangat penting dalam sebuah instansi. Laporan ini menyangkut bagaimana efektivitas kinerja pegawai selama satu bulan. Laporan kinerja berisi daftar kehadiran pegawai, daftar hal-hal yang dilakukan oleh pegawai hingga tunjangan yang didapat pegawai tersebut dalam satu bulan.

Biro Umum Pemerintahan Provinsi Sumatera Barat merupakan salah satu instansi yang membutuhkan laporan kinerja $b$ pegawai. Ada beberapa kendala yang dihadapi dalam pelaporan kinerja pegawai ini, seperti keterlambatan dalam penyampaian hasil laporan, hal ini disebabkan karena proses pengisian laporan harian pegawai masih dilakukan secara manual. Dalam rangka mengatasi permasalahan yang dihadapi oleh Biro Umum tersebut maka salah satu alternative yang dapat dilakukan adalah dengan membangun sistem kinerja pegawai yang dapat diakses secara online.

Analisa kebutuhan merupakan tahap awal dalam membangun sistem yang baru. Untuk itu digunakanlah work system framework (WSF) dalam anlisa sistem dan unified language modeling 
(UML) dalam memodelkan sistem. WSF adalah sebuah sistem yang didalamnya melibatkan partisipasi manusia dan mesin untuk menghasilkan produk atau jasa yang akan ditujukan untuk kepentingan customer didalam dan diluar (Recker \& Alter, 2012). UML adalah alat yang digunakan untuk menentukan, memvisualisasikan, memodifikasi, membangun dan mendokumentasikan pengembangan piranti perangkat lunak (Lee, 2012).

Sistem informasi adalah suatu sistem di dalam suatu organisasi yang mempertemukan kebutuhan pengolahan transaksi harian yang mendukung fungsi operasi organisasi yang bersifat manajerial dengan kegiatan strategi dari suatu organisasi untuk dapat menyediakan kepada pihak luar tertentu dengan laporan-laporan yang diperlukan.

WSF merupakan sistem yang didalamnya melibatkan partisipasi manusia dan mesin untuk menghasilkan produk atau jasa yang akan ditujukan untuk kepentingan customer. WSF memiliki beberapa ckomponen seperti customer, product and service, process and activities,participant, information, technology, dan infrastructure.

Unified Modelling Languange (UML) adalah alat yang digunakan untuk menentukan,menvisualisasikan, memodifikasi, membangun dan mendokumentasikan pengembangan piranti perangkat lunak (Lee, 2012). UML menawarkan sebuah standar untuk merancang model sebuah sistem (Sulistyorini, 2009). UML merupakan alat bantu yang dapat digunakan dalam mendesain sistem yang akan dibangun. UML merupakan standararisasi dari bahasa pemodelan dibidang ilmu komputer dan rekayasa perangkat lunak (Siddique dkk, 2009).

Laporan kinerja pegawai terdiri dari 2 komponen yaitu : laporan harian yang merupakan laporan kegiatan harian pegawai dan penilaian kinerja pegawai yang merupakan penghitungan skor kinerja pegawai terkait dengan perilaku kerja dan prestasi kerja pegawai tersebut.

\section{METODE PENELITIAN}

Metodologi adalah kerangka kerja teoritis yang dipergunakan oleh penulis untuk menganalisa, mengerjakan dan mengatasi masalah yang dihadapi. Kerangka teoritis atau kerangka ilmiah merupakan metodemetode ilmiah yang akan diterapkan dalam pelaksanaan tugas. Metodologi penelitian merupakan cara yang digunakan dalam memperoleh menjadi informasi yang lebih akurat sesuai permasalahan yang akan diteliti. Adapun kerangka kerja penelitian ini dapat dilihat pada gambar berikut:

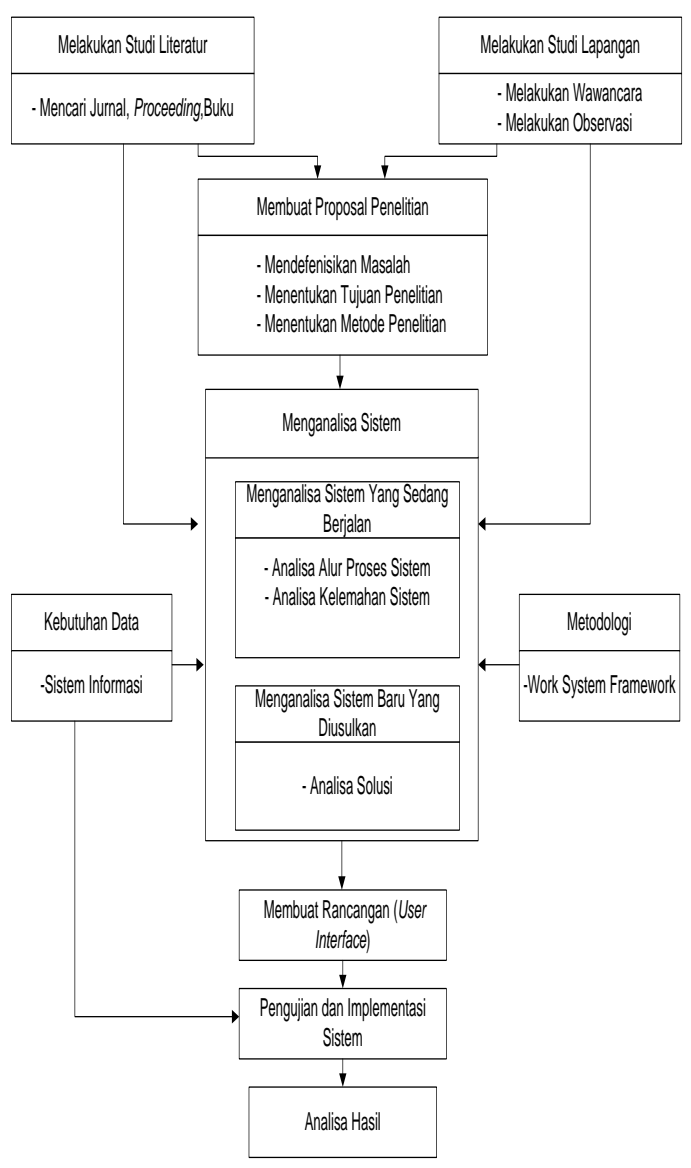

Gambar. 1 Kerangka Penelitian 


\section{HASIL DAN PEMBAHASAN}

\section{Analisa Sistem}

Analisa sistem merupakan tahap terhadap sistem yang sedang berjalan, prosedur dan alur dari sistem yang sedang berjalan, analisa permasalahan serta penentuan kebutuhan sistem.

\section{Alur Sistem yang Sedang Berjalan}

Berdasarkan analisa yang dilakukan, maka dapat digambarkan alur sistem yang berjalan dengan activity diagram seperti gambar 2 berikut:

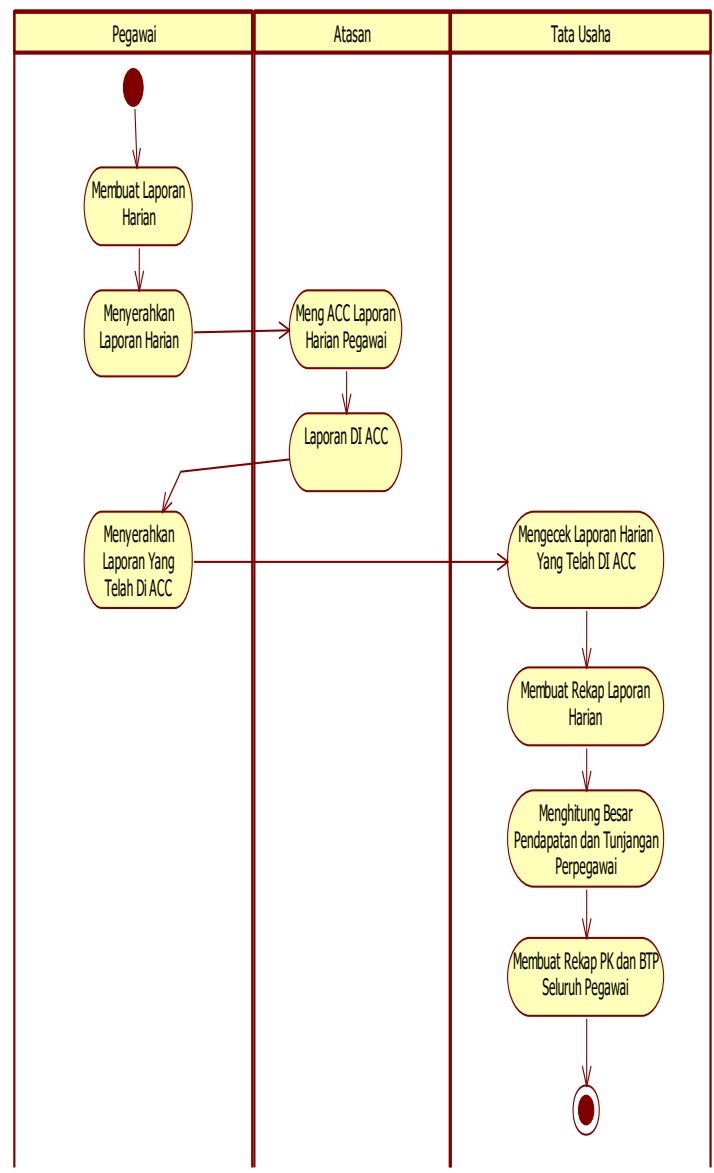

Gambar. 2 Alur Sistem yang Berjalan

\section{WSF Sistem yang Sedang Berjalan}

Berdasarkan alur proses sistem yang sedang berjalan seperti yang telah dibahas sebelumnya, maka dapat digambarkan work system framework seperti gambar berikut :

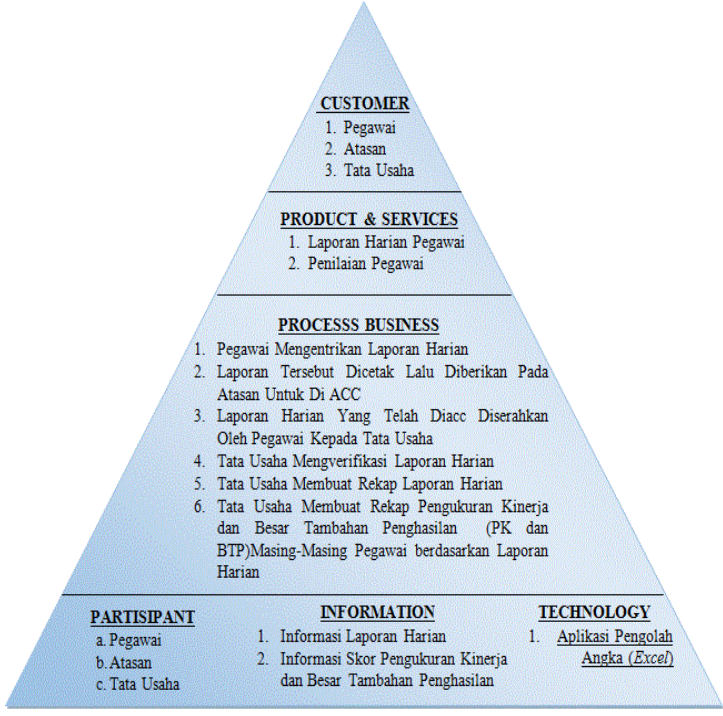

Gambar. 3 WSF Sistem yang Berjalan

\section{Analisa Sistem yang Diusulkan}

Analisa sistem merupakan salah satu tahap dalam siklus hidup pengembangan sistem informasi. Pada tahap ini akan dibahas mengenai analisa sistem yang akan diusulkan dengan harapan untuk mengatasi kendala yang dialami oleh sistem yang sedang berjalan. Adapun metode yang digunakan dalam analisa sistem yang diusulkan adalah work system Framework (WSF). Adapun sistem yang diusulkan dapat dilihat pada gambar 4 berikut:

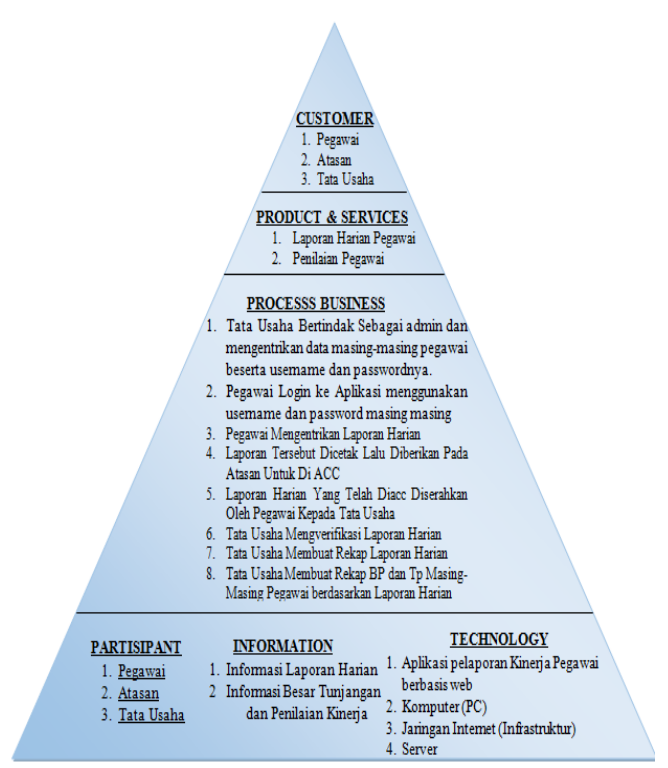

Gambar 4. WSF Sistem Usulan 


\section{Desain Sistem yang Diusulkan}

Desain sistem merupakan salah satu tahap dalam siklus hidup pengembangan sistem informasi. Pada tahap ini, akan dilakukan perancangan terhadap sistem baru yang akan dibuat disesuaikan dengan kebutuhan user. Dalam melakukan perancangan, dibutuhkan suatu alat bantu yaitu Unified Modeling Language (UML).

\section{Use Case Diagram}

Use case diagram dapat menetukan pengguna potensial dan bagaimana mereka bereaksi terhadap aktivitas dan aliran proses dalam aplikasi berbasis web (Mubin dkk, 2016). Model use case dapat dilihat pada gambar 5 berikut:

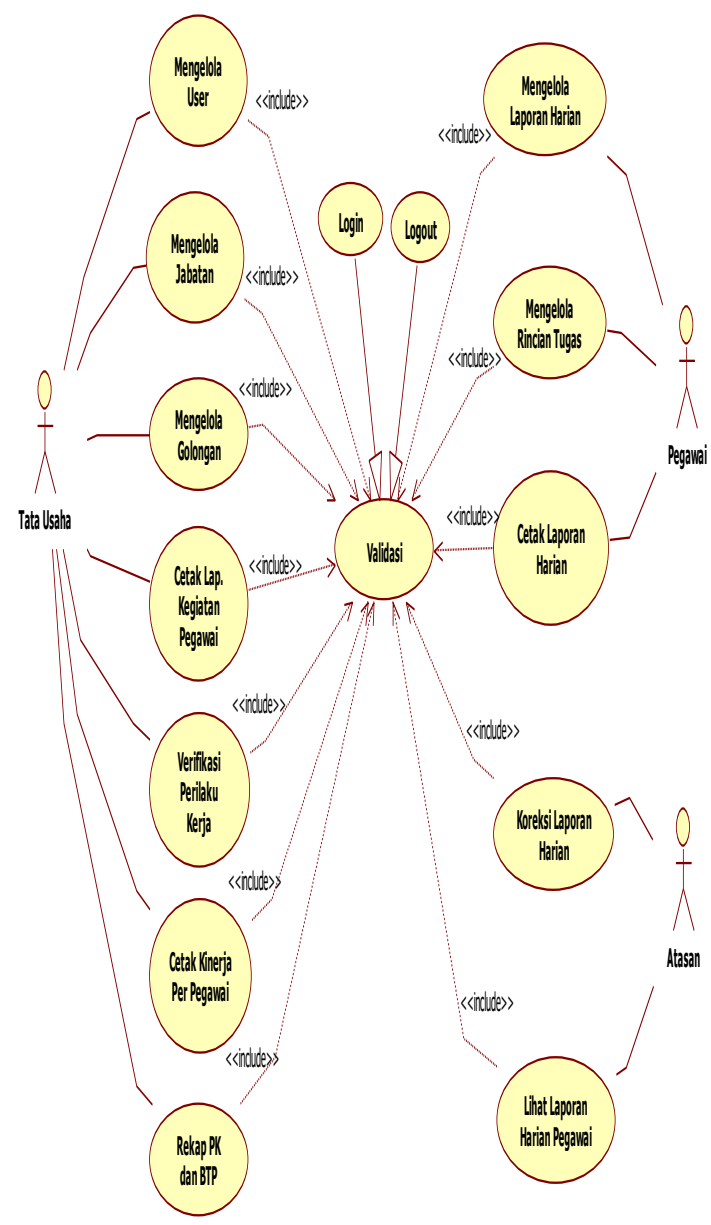

Gambar. 5 Use Case Diagram

\section{Class Diagram}

Diagram ini menggambarkan struktur statis dari kelas dalam sistem dan menggambarkan atribut, operasi, dan hubungan antara kelas (Haviluddin, 2011). Class diagram dapat dilihat pada gambar 6 berikut:

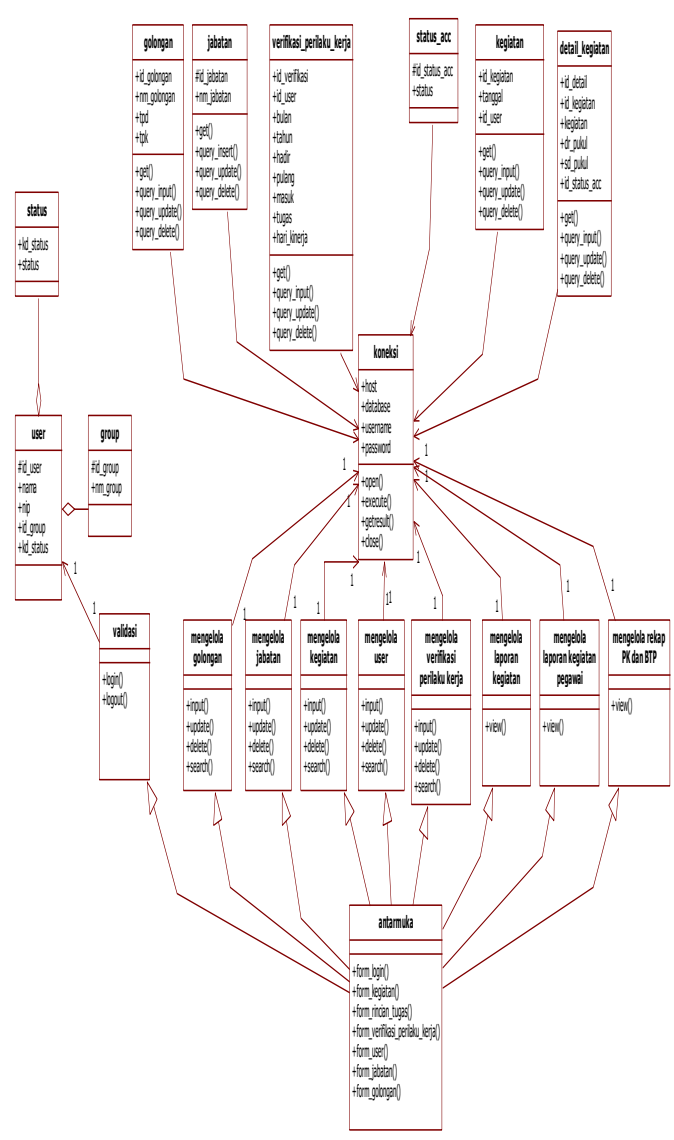

Gambar. 6 Class Diagram

\section{Implementasi dan Pengujian}

Implementasi sistem merupakan salah satu tahap dalam daur hidup pengembangan sistem informasi. Tahap ini merupakan tahap dimana sistem diatur sehingga sistem informasi siap untuk dipakai. Dalam tahap ini, berlangsung beberapa aktivitas secara berurutan yakni mulai dari menerapkan rencana implementasi, melakukan kegiatan implementasi, dan tindak lanjut implementasi. 


\section{Pengujian Sistem}

Pengujian yang dilakukan meliputi halaman input dan output sistem yang dibangun.

\section{Halaman Login}

\section{Silhakan Login Berdasarkan username masing-masing}

\begin{tabular}{|l|l|} 
Username & $\mathbf{l}$ \\
\hline Password & $\mathbf{0}$
\end{tabular}

Gambar. 7 Halaman Login

\section{Halaman Utama User}

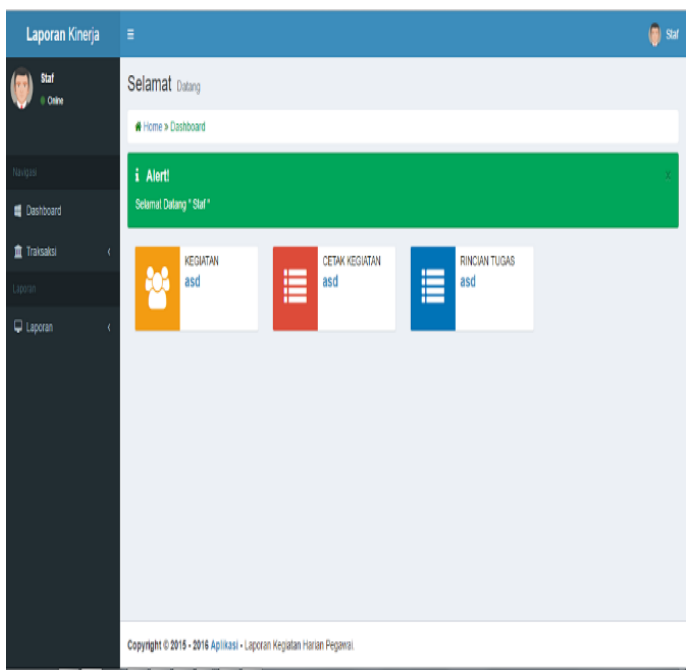

Gambar. 8 Halaman Utama User

\section{Halaman Input Tanggal}

Silankan Masukan tanggal Kegiatan

$$
\text { |si Tanggal } \text { 幽 2016-09-01 }
$$

\section{ket: : tidiak boleh Kosong}

\section{\& Kembali Q Simpan}

Gambar 9. Halaman Input Tanggal

\section{Halaman Input Kegiatan}

Tambah Kegiatan

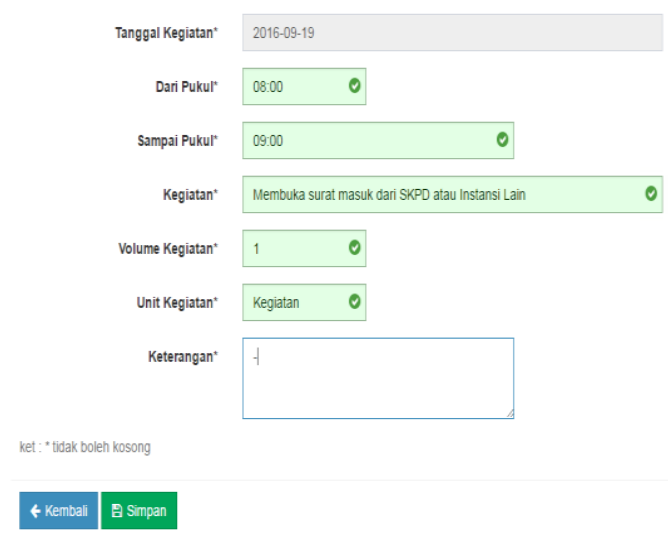

Gambar. 10 Halaman Input Kegiatan

\section{Halaman Input Data Golongan}

EEntri Data Golongan

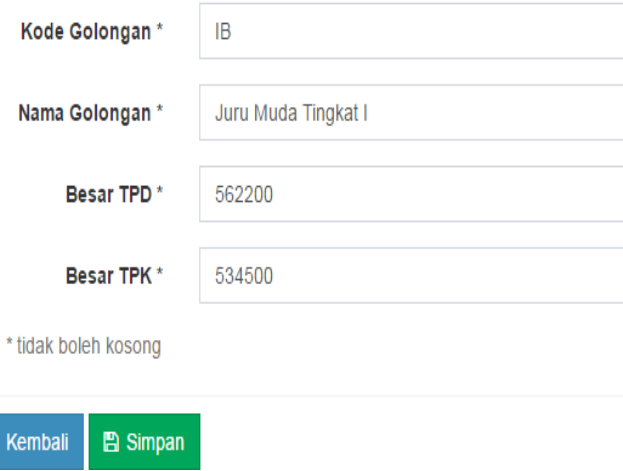

Gambar. 11 Halaman Input Data Golongan

\section{Halaman Input Data Bagian}

Tambah Data Bagian

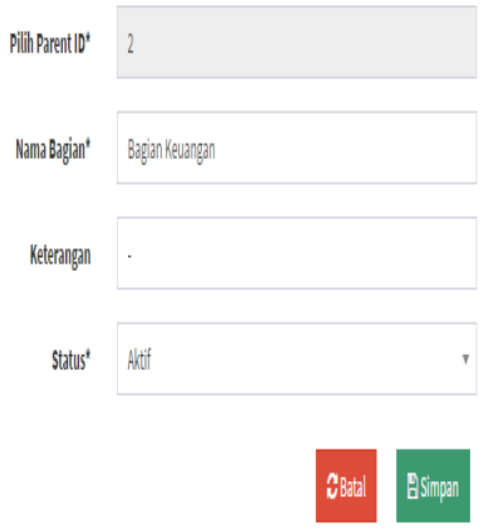

Gambar. 11 Halaman Input Data Bagian 


\section{Halaman Input Data Jabatan}

Tambah Oata I Jdatatan

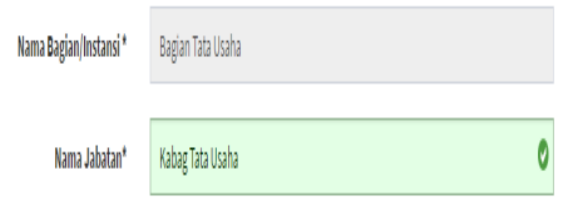

A Abatal Bsimpan

Gambar. 12 Halaman Input Data Jabatan

\section{Halaman Input Data User} Tambah Peganai

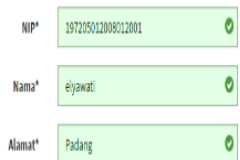

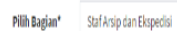

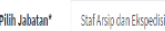

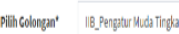

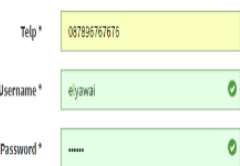

Jeniskelamin' Prencuan

States' what

Govps'

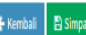

Gambar. 12 Halaman Input Data User

\section{Halaman Input Data Data} Verifikasi Perilaku Kerja

Indikator Penilaian Kinerja Pegawai

Bulan

Tahun*

Jumlah HariKerja*

Hadir terlambattannal Iin 1 Bul a

Pulang Lebihih Cepat Tanpa lijindalam 1 Bulan"

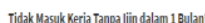

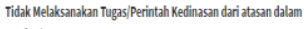

1 Bulan'

ket: "tidak boleh kosong

\section{Kenbali Q Simpan}

Gambar 13 Halaman Input Data Verifikasi Perilaku Kerja
10. Halaman Laporan Data Pegawai

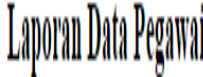

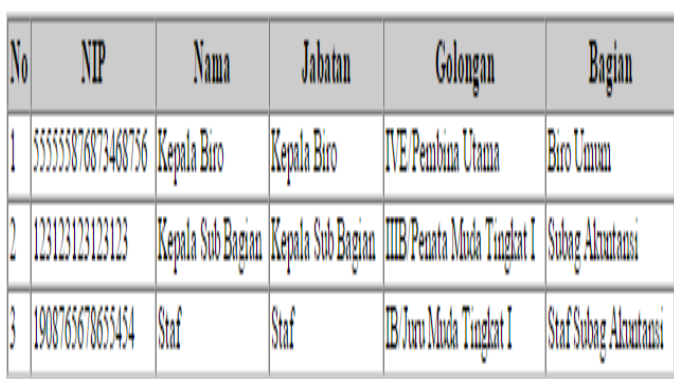

Gambar 14. Halaman Input Data Verifikasi Perilaku Kerja

11. Halaman Laporan Kinerja Pegawai

LAPORIY HARIAY

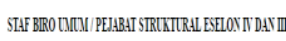

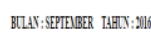

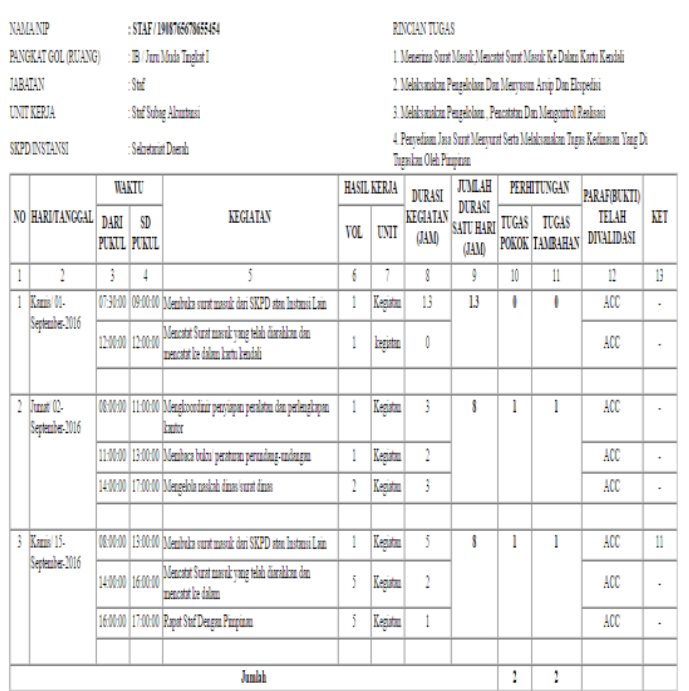

Jasthi:

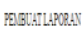

IFPPLASIBBACAY STI.

Gambar. 15 Laporan Kinerja Pegawai 


\section{Halaman Laporan Pengukuran Kinerja Pegawai}

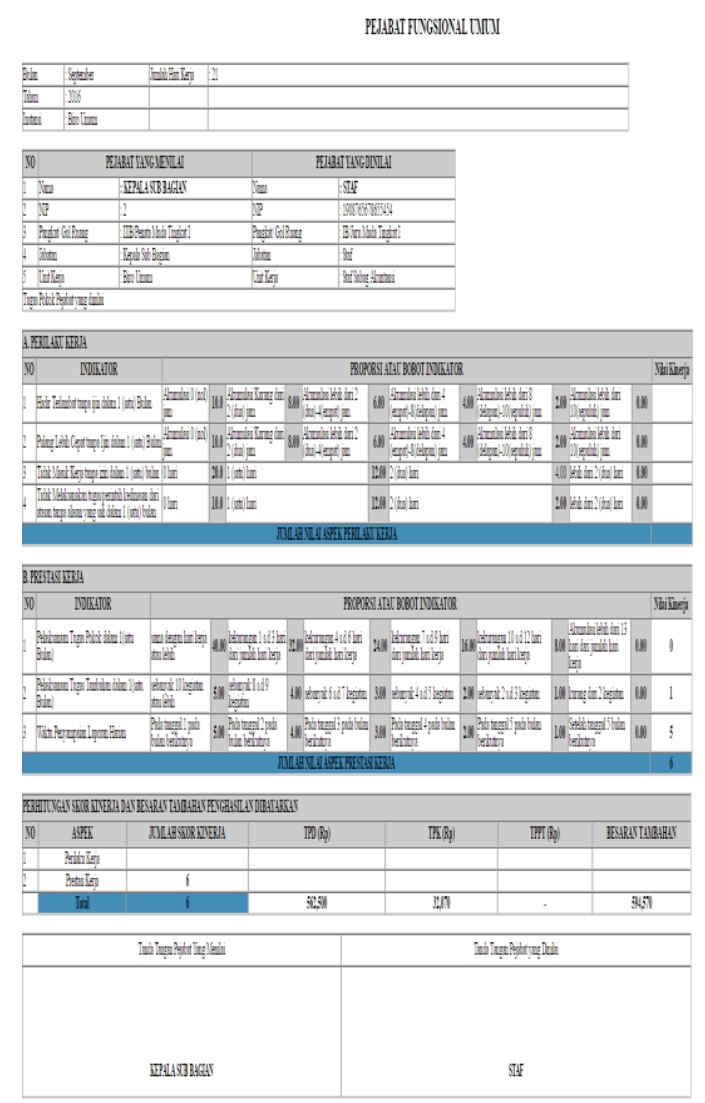

Gambar. 16 Laporan Kinera Pegawai

\section{SIMPULAN}

Penelitian ini membahas mengenai analisa dan perancangan aplikasi pelaporan kinerja pegawai di Biro Umum Pemerintahan Provinsi Sumatera Barat. Berdasarkan pembahasan pada bab sebelumnya dapat disimpulkan beberapa hal antara lain sebagai berikut:

1. Metode work system framework yang digunakan dapat memberikan gambaran dalam menganalisa dan menentukan kebutuhan (requirement) serta alur proses sistem yang sedang berjalan dan kekurangan-kekurangan sistem sehingga dapat diusulkan sistem baru yang diharapkan dapat mengatasi kekurangan tersebut.
2. Berdasarkan kebutuhan dan analisa alur proses sistem yang telah dianalisa, maka dibutuhkan suatu pemodelan sistem dengan Unified Modelling Languange (UML). Dengan mengunakan UML maka mekanisme kerja sistem dan komponen-komponen yang terlibat dapat dijelaskan.

3. Sistem yang diusulkan berupa prototype yang dikembangkan dengan bahasa pemograman PHP yang didukung dengan database MySQL.

4. Prototype sistem yang dibangun telah selesai dibuat dan diharapkan dapat mengatasai keterlambatan dalam penyampaian laporan harian pegawai perbulan.

\section{DAFTAR PUSTAKA}

Haviluddin, H. (2011). Memahami Penggunaan UML (Unified Modelling Language), Jurnal Informatika Mulawarman, 6(1), $1-15$

Lee, S. (2012). Unified Modeling Language (UML) for Database Systems and Computer Applications. Int. J. Database Theory Appl, 5(1), 157-164

Mubin, S. A., Jantan, A. H., Abdullah, R., \& Kamaruddin, A. (2016). UML-Based Conceptual Design Approach for Modeling Complex Processes in Web Application. Int. J. Appl. Eng. Res, 11(6), 9734562

Recker, J. C. \& Alter, S. (2012). Using the Work System Method with Freshman Information Systems Students. J. Inf. Technol. Educ. 11, 1-24

Siddique, Q., Iaeng, M., \& Main, A. (2010). Unified Modeling Language to Object Oriented Software Development, 1(3), 264-268 
2018. Intecoms:Journal of Information Technology and Computer Science 1(2):151-158

Sulistyorini, P. (2009). Pemodelan

Visual dengan Menggunakan

UML dan Rational Rose. $J$.

Teknol. Inf. Din, 14(1), 23-29 